\title{
Evaluate Professional and Amateur Athletes' Social Insurances with Legal Aspects in Turkey.
}

\author{
İ. Bülent FIŞEKÇIOĞLU ${ }^{1}$, Arif ÖZSARI ${ }^{1}$,H. Fatih ŞEN ${ }^{1}$,M. Mehmet ALTIN ${ }^{1}$, \\ Alpaslan GÖRÜCÜ1 \\ 1 Selcuk University, Sport Sciences Faculty, Konya, Turkey \\ Address Correspondence to İ.B. Fişekçioğlu e-mail: bfisekcioglu@selcuk.edu.tr
}

\begin{abstract}
With this study, we aimed to evaluate professional and amateur athletes' social insurances with legal aspects in Turkey.In this study -which was prepared by making use of descriptive analysis- related laws, regulations and literature were reviewed and the recent situation was demonstrated by researching the obtained resources. It's understood that professional and amateur Athletes' contracts are a sort of service contracts, but neither group is subject to Labor Law No. 4857, therefore they cannot demand severance pay, notice pay or annual leave; and that general and special provisions of Law on Debts No. 6098 were implemented for the athletes who signed a contract with a club; and it is also understood that state athletes, jockeys and foreign athletes were subject to the Law On Social Insurance and General Health Insurance No.5510; and that, amateur athletes who have a contract with a club were evaluated in the scope of private health insurance, despite that, amateur athletes without contract to any club aren't subject to social insurance provisions.
\end{abstract}

Key words: Athletes, Social Security.

\section{INTRODUCTION}

Social security as defined in the universal declaration of human rights; "Measures to compensate and compensate for the damages of the hazards that occur outside the wishes and wills of individuals, which in turn lead to losses in their assets, revenues and / or working power, and to make the lives of their dependents more difficult or impossible" (9). In other words, social security is to ensure the safety of all individuals against the loss of income and the increase in expenses caused by certain social risks (19).

The purpose of social security is to protect the person against the risks that are subject to social security. In other words, it is to protect the individuals against the economic consequences of social risks such as illness, accident, old age, disability, death, unemployment and child rearing which may come from inside or outside of working life (14). A number of tools are used when performing protection tasks. These tools can be listed as social insurance, social services and social assistance. Social insurance is the most advanced and widespread of social security techniques. A certain number of social risks that employees may be exposed to in a country is an insurance technique to be met by an autonomous, self-governed institution established and organized by the state with the participation of workers and employers (18). Social services, which is another social security tool, are the services aimed at creating an environment in which individuals can survive in accordance with the general conditions of the country they live in, and to help the solution of their social and economic problems (27). In the face of the extraordinary and unplanned social events and social risks that sometimes arise, no matter how advanced the social insurance system of a state is today, an insurance system cannot fulfill the basic goals of social security in a way that encompasses everyone. Social aids at this point are often help from the state budget for those who are born poorly for reasons not in their own hands or who are subsequently deprived of poverty and therefore need help in the absolute sense or who are partly in need of help because they do not have sufficient income (3).

Sport is one of the most widespread and effective social institutions of modern societies (35). Sports in the world and in our country every year, developing rapidly compared to the previous year, and professional and amateur sports every year by 
increasing the number of people who work rapidly increasing. Nowadays, sports are becoming more and more popular and become an interest of individuals working in many fields (2). It is important to note that it is essential to ensure the continuity of sports, which is a social institution, and the athletes performing the performance of this institution in a healthy and orderly manner with legal arrangements. This study of professional and amateur athletes in Turkey has tried to present the current social security situation.

\section{METHOD}

In this study, which is designed according to qualitative research model, document (document) examination model is used. Document review; the examination of documents in qualitative research, archive records, and the collection and analysis of the data of the research subject of various materials (11). In this study, relevant laws, regulations and related literature have been searched and the current situation has been examined.

\section{Social security in sports for legal size}

Republic of Turkey in the 59th article of the Constitution: "The State shall take measures to develop the physical and mental health of Turkish citizens of all ages, sport encourages the spread of the masses", while in the 60th article, "everyone has the right to social security. The State shall take the necessary measures to establish this security and establish its organization (30).The relevant provisions of the Constitution of the Republic of Turkey on the general framework is thought to be considering legal requirements of athletes take part in the social security system in the Republic of Turkey.

\section{Sport And Sports Concepts}

Sports, personal or collective games can be defined as all of the body movements performed according to a set of rules that usually lead to competition and competition. According to this, sportsmanwho is engaged in sports, actively involved, competing, match maker (13).

\section{Professional Athletes}

Professionalism means that the athlete is engaged in a certain organization in order to gain a material profit. Professional athletes make sports as a profession to make a living and to survive (15). In order for a sports branch to become professional in the Turkish sports sector, according to Article 24 of the Law on Youth and Sport Services No. 3289, the determination of this professional sports branch by the Ministry of Youth and Sport and the establishment of this professional sports branch, (4/35). In Article 18 of Law No. 3289 entitled Formation of federations and determination of professional branches mad, one or more sports branches are connected to one federation, both technically and administratively. The number of amateur federations and professional branches are determined by the Ministry of Youth and Sports. Amateur and professional football activities carried out by two separate boards connected to the Turkey Football Federation ", is situated phrases; Furthermore, it is stipulated that the provisions of Law no. 3289 on professional football shall not be applied (32/35).

Today, as in some European countries, Turkey too is seen only when it is recognized athletes in the framework of the legal regulations of professional identity in the football industry. Indeed, Turkey Football Federation, 16.05.2009 date and published in 27230 Official Gazette No. 5894 dated Turkey Football Federation establishment and status of professional footballers as interests in accordance with the law on duties and transfer authorization, professionalism in football and has determined amateurism requirements and guidelines. Accordingly, in the third article of the instruction entitled"professional footballers fied, the professional football player is defined as" a footballer who has signed a club with a contract and who is paid a greater amount than the expenses he incurred in football activities, If the amateur football player in Article 4 of the instruction is defined all footballers who are excluded from the definition mentioned in article three are considered as amateur footballers (32).When the related laws, regulations, instructions and communiqués are examined, all sports except football are legally regarded as amateur. It should be noted that all sports except football are authorized to regulate the Ministry of Youth and Sports $(2,15,20,31)$

\section{Social Security of Professional Athletes}

Clubs, professional athletes and pay the price of doing business. Therefore, legal relationships of professional athletes with employers are based on a service contract (26). However, professional athletes are not subject to labor law no. 4857 and therefore cannot demand severance pay, notice of compensation and annual leave in accordance with 
the provisions of the labor law. In accordance with Article 393 of the Code of Obligations, athletes working in a certain club under contract with the special provisions governing the service contract and the general provisions are applied legislation $(18,2)$.

In this context, professional athletes are insured within the scope of the service contract within the scope of Social Security and General Health Insurance Law no. 5510 (24). Profits of professional athletes based on premiums, social securityand according to Article 80 of the Universal Health Insurance Law. Professional sports clubs are obliged to notify the Social Security institution of their athletes (21).

\section{Amateur Athletes}

The concept of amateurism, which is derived from the word land "amare" mas which means. Love 1 in Latin, means that the athlete likes to do sports because he likes and likes. To be able to talk about amateurism in this sense, the athletes should not have chosen the sport as a profession and the sport should not be made in order to generate continuous income (15).

\section{Social Security of Amateur Athletes}

Athletes contracts signed between athletes and clubs are contracts that pay debt to both parties. Under this contract; athletes, their own branch in the name of the club to compete or to compete, in matches or competitions are required to show the maximum performance, the club against this service to pay the athlete's wages in time, if there are other acts under the contract to fulfill them, the athlete is obliged to give the premium stipulated in the contract with the athlete. The amateur athletes are excluded from the scope of the Labor Law in accordance with the paragraph (g) of Article four of the Labor Law No. 4857, as professional athletes (12). Amateur athletes work on the basis of the service contract because of the provisions of the Law No. 55104 / a paragraph of the provisions of insurance $(2,21,24)$.

However, amateur athletes have made various arrangements. These regulations are as follows:In accordance with the provisions of the General Health Insurance, which was put into force by the Implementation Law no. 5510 in 2013, various additions were made. Athletes older than 18 years of age can be covered by the health insurance by the first, second and third teams in the Olympic Games, at the World or in the European Championships as a team in individual or team sports $(24,26)$.

On 10.04.2013, the Ministry of Health and the Ministry of Youth and Sports, independent federations affiliated to the Ministry of Youth and Sports and TFF, and amateur athletes who could not benefit from the health assistance of any social security institution were signed a protocol on the provision of health services from the health institutions affiliated to the Ministry of Health $(19,21,26,36)$. Athletes who are licensed and who do not have any health insurance can benefit from this protocol.

In some sports (basketball, handball, volleyball, etc.) private health insurance system is used. The weak point is the assurance of amateur athletes who have no more contracts. Article 393 of the Turkish Code of Obligations dated 11/1/2011 and Article 6098 of the Turkish Code of Obligations provides for the provision of spor service contracts spor to the amateur athletes working in a certain club, the special provisions governing the service contract and the general provisions of the law on the related sports branch. On the other hand, it is necessary to state that amateur athletes engaged in sports without any fee from their clubs are not subject to the social insurance law no $5510(2,16)$.

\section{Social Security Provisions in Amateur Sports} Federations

There are a total of 63 amateur sports federations in Turkey. Federations are established in accordance with the relevant articles of the Law on Youth and Sports Services No. 3289. An important part of the federations in our country is an independent sport federation. Implementing Regulation on Working Procedures and Principles of Independent Sport Federations dated 9 July 2012.It was put into effect after being published in the Official Gazette No. 28358. Taking the necessary measures on issues related to the health of the athletes gere in the scope of Article 6, title,duties and Authorities of the Federation gere, is included in the related regulation $(5,23)$. The sports federations, except the football federation, are preparing the regulations in accordance with this regulation. The social security provisions that can be reached in amateur sports federations are shown in the table below within the framework of the relevant legislation. 
Table 1. Social Security Provisions in Amateur Sports Federations

\begin{tabular}{|c|c|c|}
\hline Basketball & $\begin{array}{l}\text { Turkey Basketball Federation of Association } \\
\text { Board of Directors' Duties Article12: } \\
\text { Basketball, manager, coach, technical staff, } \\
\text { referee, technical commissioner, basketball } \\
\text { player, masseur and similar elements to make } \\
\text { the necessary arrangements for education, to } \\
\text { take all kinds of measures to develop these } \\
\text { elements, to provide social security rights to } \\
\text { make regulations, to prepare and implement } \\
\text { the status and instructions } \\
\text { (29). }\end{array}$ & $\begin{array}{l}\text { Turkey Basketball Federation Basketball Contractual } \\
\text { Licensing, Registration and } \\
\text { Transfer Instructions Obligations of Clubs Article 26: } \\
\text { To register the social security institution after signing the } \\
\text { contract and to keep the basketball player's contract until the } \\
\text { expiry date and to pay the premiums. } \\
\text { 1)The club will be notified to the SGK to notified. } \\
\text { 2)Negligence seen club managers SSI notified (6). }\end{array}$ \\
\hline Handball & $\begin{array}{l}\text { Turkey Handball Federation's Duties and } \\
\text { Powers Article } \\
\text { To take necessary precautions in the subjects } \\
\text { related to health of athletes (36). }\end{array}$ & $\begin{array}{l}\text { Sportsman Registration License and Transfer Instruction } \\
\text { Article 6: } \\
\text { Document indicating that the athlete was insured from } \\
\text { official and private health institutions (36). }\end{array}$ \\
\hline Volleyball & \multicolumn{2}{|c|}{$\begin{array}{l}\text { Turkey Volleyball Federation Volleyball Athlete Registration, License and Transfer Instructions Article 7: } \\
\text { If the contract is signed between the club and the athlete, it is the club's responsibility to insure and follow the } \\
\text { athlete in accordance with the provisions of the SSI legislation. The notarized signature circular of the athlete is } \\
\text { handed over to the federation licensing office with the contract (33). }\end{array}$} \\
\hline
\end{tabular}

63 amateur sports federation, the relevant regulations and instructions can be accessed by reviewing social security provisions were examined. As a result of the research conducted in the main status of the amateur sports federations in the main status of the following text has been shown: are in the area of duty within the scope of the Federation, manager, manager, coach, trainer, instructor, masseur, technical staff, referee and similar elements to train, to take all kinds of measures for development, to coordinate with relevant clubs and / or units on social security rights, to determine the procedures and principles related to their club exchanges and activities.

As it is seen, it is obvious that the concept of athletes in this text is not sufficiently given to the social security phrase of the athletes and it can be said that basketball, handball and volleyball federations are more sensitive to social security. However, the need to take a long way about the social security of amateur athletes has emerged once again.

As mentioned above, amateur athletes engaged in sports in any club with the service contract are evaluated within the scope of private compulsory health insurance. Private health insurance system is used in multi-league branches such as basketball, handball and volleyball. It should also be noted that amateur athletes engaged in sports without paying any fee to their clubs are not subject to the social insurance system and that the regulations on the social security of amateur athletes have not been adequately covered in the regulations introduced by the federations. Social security does not merely represent a guarantee against health risks (injury, disability, etc.), but against inevitable situations such as old age and death. The more important sporting success for the athlete, the more robust a pension is in old age.

Turk ل Sport Exe 2019; 21(2): 211-216

(4) 2019 Faculty of Sport Sciences, Selcuk University

\section{Social Security Practices for Athletes Presenting}

\section{Differences}

Jockeys, national athletes, state athletes (sportsman's honor) and foreign athletes are able to evaluate in this category.

\section{Jockeys}

The jockey and coaches subject to the Law on Horse Races dated 10.07.1953 and numbered 6132 have the phrase law Provisions for those who are insured under Article 4/1 B of the Law No. $551010(25,26)$.

\section{National Athletes}

Article 23 of the Law on Youth and Sport Services regulates the insurance of national athletes. The athletes selected for the national teams and the technical staff of these teams, from the beginning of the camp work to the residence of the students after the competition, and the other officials in the national team list from the dates of the competition to the date of arrival to the residence, It is insured against the special insurance system. The principles and procedures of insurance are regulated by regulation $(10,35)$.

In order to determine the principles and procedures of these insurance transactions prescribed by the Law, the Regulation on the Insurances of National Team Members was published by the General Directorate of Youth and Sports published in the Official Gazette dated 13.8.1991 and numbered 20959. This regulation covers the national athletes who form the civil and military teams other than professional football activities, the manager, the technical staff and all other personnel assigned to these teams. These persons are required to be insured by private insurance companies and insurance premiums are covered by the General Directorate. The 
amount of insurance costs is determined by an instruction issued by the general Directorate of Youth and sports each year $(17,18)$.

\section{State Athletes (athlete's honor)}

With the Law No. 5774 on providing the Name of the State Athlete with the Monthly Attachment to the Successful Athletes, the name of the pension granted to the successful athletes is defined as the Athlete's Honor pension. According to the 2nd article of Law No. 5774, acceptance In the category of adults who have been accepted by the International Olympic Committee (IOC) as an Olympic, Paralympic and defective sport in the period of competitions; In the Olympic Games, at the World or European Championships, the first, second and third amateur athletes in the team or in individual teams and their spouses and children in the event of their death, and the national team coach and coaches of the amateur athletes who are Olympic or world champions in teams (7). The amateur athletes who are given the title of State athlete are bound by the decision of the Council of

\section{CONCLUSION AND RECOMMENDATIONS}

Social security; It can be said that it protects people from diseases, accidents, dangers throughout their lives and includes the periods when their work abilities are reduced or disappeared.Athletes, One of the sides of the sports world, are divided into two parts as amateur and professional. Considering factors such as labor, time and experience spent on sports, only the distinction between amateur and professional athletes is contrary to the system of social security (2).

Both professional and amateur athletes are excluded from the scope of labor law in accordance with Article 4 / g of Labor Law No. 4857. For this reason, it is not possible to consider the athletic contracts as a labor contract. The relationship between the athlete and his club is the, Service Contract and, which is regulated in Article 393 of the Turkish Code of Obligations No. 6098 dated 11/1/2011. The provisions of the Turkish Code of Obligations related to the service contract and the related sports branch are applied to this relationship (16). Professional athletes have social security rights even if they are not covered by the Labor Law. Professional athletes under the Article 4 / a of Law No. 5510 employer those employed by one or more employers by the service contract dais are counted as 4 / a insured (21) For amateur athletes other than professional athletes, the provisions of $4 / \mathrm{a}$ of the Law No.5510 are not applicable (1/24).

Turk J Sport Exe 2019; 21(2): 211-216

๑ 2019 Faculty of Sport Sciences, Selcuk University
Ministers under the name of in Sportsman's Honor Pension Turk with the decision of the Council of Ministers to be started from the date they are 40 years old and they maintain their Turkish citizenship. Again, the athletes who died while receiving an honorary pension, their spouses and their children are given this monthly by adhering to the social security laws (23).

\section{Foreign Athletes}

It was possible for foreigners to work in our country within the framework of article 5 and 6 of the Law No 4817 on Work Permits of Foreigners (12); However, with the International Labor Law No. 6735 published in the Official Gazette dated 13/8/2016 and numbered 29800, work permit for foreign players, foreign coaches and other athletes is obligatory (34). This law covers not only football clubs, but also all sports clubs.With the exception of those who are in the national social security agreement based on reciprocity, the employees who are contracted with the service contract from foreign nationals have been accepted as insured under Law 4 / $a$ and c (24).

Amateur athletes engaged in sports in any club with the Service Agreement are considered within the scope of private compulsory health insurance. Private health insurance system is used in multi-league branches such as basketball, handball and volleyball. On the other hand, it is important to note that the amateur athletes engaged in sports without paying any fee to their clubs are not subject to the social insurance system and that the regulations on the social security of amateur athletes are not sufficiently included in the regulations introduced by the federations. Athletes with varying conditions such as jockeys and foreign athletes are subject to insurance provisions under Article 4 / a and $c$ of Law No. 5510. The amateur athletes who are given the title of State athlete are bound by the decision of the Council of Ministers under the name of in Sportsman's Honor Pension Turk with the decision of the Council of Ministers to be started from the date they are 40 years old and they maintain their Turkish citizenship. Again, the athletes who died while receiving an honorary pension, their spouses and their children are given this monthly by adhering to the social security laws (23).

In almost all of the studies conducted on the social security of athletes from the past to the present, there are many suggestions regarding this situation by emphasizing that the missing point is the social security of the athletes. However, as of today, it is not possible to say that there is a 
complete solution to this issue. In the determination of the social security of the employees of the sports field, it is necessary to look at the Labor Law, the Code of Obligations, the Social Security Law and the instructions issued in the field, in particular in relation to the professional sports field. In other words, it is not possible to talk about a totality $(2 / 15 / 20)$.In the light of all this, taking into account the needs in practice, regardless of whether a sport branch is legally recognized as a professional or not,Professionalism-amateur distinction is not suitable for sports, but for athletes. Professional sports gün and ortaya professional sportsman ası concepts need to be separated from each other (15). Again, the legal arrangements to be made on the basis of this distinction and the legal status of both amateur and professional athletes in terms of social security needs to be stabilized and secured.

\section{REFERENCES}

1. Amcaoğlu D, Yetim A. Sporcuların sosyal güvenlik bilgi düzeylerinin incelenmesi. İ.Ü. Spor Bilimleri Dergisi, 2018, 8(1),1303-1414.

2. Amcaoğlu D. Sporcularda Sosyal Güvenlik. Yüksek Lisans Tezi, Gazi Üniversitesi Sağlık Bilimleri Enstitüsü, Ankara.2015.

3. Arpat B.Türk sosyal güvenlik hukukunda genel sağlık sigortası. Yüksek Lisans Tezi, Sakarya Üniversitesi Sosyal Bilimler Enstitüsü, Sakarya,2009.

4. Aydın U, Yüce A, Yalız D, Demirkaya S. Türkiye'de profesyonel sporcuların çalışma koşulları ve örgütlenme eğilimleri. Çalışma ve Toplum Dergisi, 2017, 4,55, 1873-1912.

5. Bağımsız spor federasyonlarının çalışma usul ve esaslar hakkında yönetmelik. www.mevzuat.gov.tr.2012.

6. Basketbolcular-lisans-tescil-ve-transfer-talimatı. 2018.www.tbf.org.tr

7. Başarılı sporculara aylık bağlanması ile devlet sporcusu unvanıVerilmesihakkındakanun/5774.www.mevzuat.gov.tr. 2009

8. Çolak S.Yabancı personelin Türkiye'deki sosyal sigorta yükümlülüğü ve özellikli konular.2014.www.verginet.net

9. Dağ C. Türk genel sağlık sigortası sisteminin seçilmiş bazı ülke sistemleri ile karşılaştırmalı analizi. Doktora Tezi, İstanbul Üniversitesi Sosyal Bilimler Enstitüsü, İstanbul. 2013

10. Gençlik ve Spor Hizmetleri Kanunu.1986. www.mevzuat.gov.tr/

11. Gürbüz S, Şahin F. Sosyal bilimlerde araştırma yöntemleri. Seçkin Yayıncılık. Ankara. 2017

12. İş Kanunu/4857.www.mevzuat.gov.tr.2003

13. Kaya K. İş kanunları kapsamında sporcu tanımı ve iş kanunlarındaki yeri. https://avukatkemalkaya.wordpress.com.2014.

14. Koç M.. Sosyal güvenliğin kökeni, Endüstri İlişkileri ve İnsan Kaynakları Dergisi, 2004,2, 217.

15. Küçükgüngör E. Türk hukukunda sporcuların hukuki durumları. Gazi Üniversitesi Hukuk Fakültesi Dergisi 1998,2,1.
16. Mertvan Avukatlık Bürosu. Spor hukuku, sporcu sözleşmeleri ve alacak hakları. www.mertvan.com.tr.2018 Milli Takım Mensuplarının Sigortalanmaları Hakkında Yönetmelik.www.mevzuat.gov.tr. 1991

17. Mil HB.Türkiye'de spor kulüpleri ve sporculara yönelik sosyal güvenlik uygulamalarının incelenmesi ve değerlendirilmesi. Yüksek Lisans Tezi, Polis akademisi güvenlik bilimleri enstitüsü, Ankara. 2010.

18. Oral İ. Sosyal Güvenlik Hukuku. Anadolu Üniversitesi Yayınları, Eskişehir.2004.

19. Öner S.Sporda sosyal güvenlik. Yüksek Lisans Tezi, Selçuk Üniversitesi Sağlık Bilimleri Enstitüsü, Konya. 2011.

20. Öztuna B. Türk sporcularının sosyal güvenliği. İnternational Joural of Science Culture and Sport,2015 3,802-808.

21. Profesyonel futbolcuların statüsü ve transferi talimat1.www.tff.org.tr.2016.

22. www.resmigazete.gov.tr. 2008/2012.

23. Sosyal sigortalar ve genel sağlık sigortası kanunu/5510. www.mevzuat.gov.tr.2006

24. Tekin O. 5510 sayılı kanun ve sosyal güvenlik reformu kapsamında isteğe bağlı sigortalılık. Yüksek Lisans Tezi, Selçuk Üniversitesi Sosyal Bilimleri Enstitüsü, Konya.2010

25. Tekin, Y., Mucuk, B., Sunay, H.Türkiye'de amatör sporcu olmak. Ankara Üniversitesi Spor Bilimleri Fakültesi Spormetre Dergisi, 2016,14,2, 183-190.

26. Tuncay AC, Ekmekçi Ö. Sosyal güvenlik hukukunun esasları, 1. Baskı, Legal Yayıncılık, İstanbul.2008

27. Türk borçlar kanunu/ 6393 www.resmigazete.gov.tr. 2011

28. Türkiye basketbol federasyonu ana statüsü. www.tbf.org.tr.2014

29. Türkiye Cumhuriyeti Anayasası www.mevzuat.gov.tr.1982.

30. Türkiye Futbol Federasyonu Kuruluş-ve-GörevleriHakkında Kanun/ 5894.2009.

31. Türkiye Futbol Federasyonu profesyonel futbolcuların statüsü ve transferleri talimatı. www.tff.org. 2016.

32. Türkiye Voleybol Federasyonu Sporcu Tescil, Lisans ve Transfer Talimatı. www.tvf.org.tr. 2014.

33. Uluslararası iş gücü kanunu/6735. www.mevzuat.gov.tr.2016. www.gsb.gov.tr

34. www.thf.org.tr/mevzuat.2014

35. Yetim A. Sporun sosyal görünümü. Gazi Beden Eğitimi ve Spor Bilimleri Dergisi,2000,5.1,63-72. 